\title{
RURAL AREAS FROM DEMOGRAPHIC PERSPECTIVE. STUDY CASE POLAND AND ROMANIA
}

\author{
COSMINA-SimONA TOADER ${ }^{1}$, MALGORZATA ZAJDEL ${ }^{2}$, \\ Andrea Ana Feher ${ }^{1}$, Malgorzata MichalceWicz-KanioWska ${ }^{2}$
}

\author{
${ }^{1}$ Faculty of Farm Management, Banat's University of Agricultural Sciences and Veterinary \\ Medicine "King Michael I of Romania" from Timisoara, Romania \\ Timisoara 300645 Aradului St. 119 \\ ${ }^{2}$ Faculty of Management, University of Technology and Life Sciences in Bydgoszcz, \\ Poland
}

Bydgoszcz 85-790 Fordońska St. 430

cosminatoader2003@yahoo.com

\begin{abstract}
The rural area is an extremely varied area, agricultural area, the area occupied by forests and grazing the surface of non-agricultural lands (Riviera sea, etc.) and rural agglomerations is a separate entity from the urban areas characterized by a high demographic concentration and vertical and horizontal structures.

Being often under the impact of old production systems, characterized by accelerated development and irrational of industry, the countryside has been subject to economic transformation, social and environmental, which mostly resulted in exodus and impoverishment of the rural population. Given this situation, are downright remarkable efforts of developed countries and not only to balance rural-urban ratio, reconciliation and revival of rural areas is kept of unique material and spiritual values.

Rural areas are the result of interactions between man and nature, between interdependencies relations, who are specific to diversity of social actions and their natural environment, between the material and spiritual civilization, which for centuries coexist and evolve in a particular national territory. Image of rural area is emphasized by its size, which is the synthetic expression of social activities that are conducted using specific processes and phenomena of nature. All specific features of rural areas (natural, human, material and spiritual), which define the dimension of rural areas, are highlighted by the following components of the system: territorial administrative, demographic, economic and infrastructural.

European rural area was and is the subject of extensive restructuring processes that were the result of a complex interaction of social phenomena, economic, sectoral and regional transfers. In circumstances where over half of the 27 Member States of the European Union lives in rural areas, and it occupies over $80 \%$ of the total territory, rural areas have considerable potential for growth, with a vital social role. Rural population and surface area occupied and the importance of rural life for a country, make the problem of rural development to gain a national and international importance.

In this article the authors presents rural areas as an important part of a country with all its components. The authors elaborated a comparative analysis of rural areas from Poland and Romania from demographic perspective. The analysis was elaborated using indicators like population density, population structure by gender and age, migrations of population, relying on data from national and european statistics.
\end{abstract}

Keywords: rural areas, population, Poland, Romania

\section{INTRODUCTION}

Rural area covers the area belongs the communes and periurban areas of cities or municipalities in which runs activities falling under agricultural production, processing of agricultural products, forestry, fisheries and aquaculture, as well as craft activities, craft and small industry and tourism services and leisure on countryside (MATEICA, 2010).

Demographic processes in rural areas are characterized by a certain dynamics, and the human factor in these areas is differentiated spatially. It is possible to distinguish peripheral areas, where generally there is little social mobility and urban areas with high intellectual and occupational potential (BRAD ET AL., 2011). 
In rural areas demographic processes are characterized by phenomena such as the size and structure of the family, its fertility, the occurrence of multiple generations and the missions that children should fulfill (MATEOC-SîRB, 2002). Rural families live not only in symbiosis with nature, but in the process of its creative processing create new values. In turn, the rural population, bound by blood ties, produces a specific social climate that affects the character of the farm.

The rural family is usually associated with the household and the farm, where the process of extended reproduction takes place, allowing the continuity of the economy and the multiplication of property goods. But the village is not only an agricultural family, but more and more often the other professions necessary for the local environment. This phenomenon leads to multifunctional development of rural areas.

\section{MATERIAL AND METHOD}

Studying different sources from the specialized literature, mentioned in the references section, followed by data processing and analysis, the authors of the article, want to highlight the similarities and differences between rural population from Poland and Romania.

\section{RESULTS}

The village as a local environment was always inhabited mainly by farmers, although this original feature of population homogeneity was corrected by the emergence of other occupational categories that assisted in the functioning of the farm. Over time, the village was inhabited by people not directly involved in agriculture, but had a great influence on shaping the intellectual potential of the countryside in the form of teachers, people of culture or administration, which fostered the diversity of the environment.

The analysis of the rural population over a longer period of time shows that in Poland the number of inhabitants between 1950 and 2015 is almost the same, an average of about 15 million people. On the other hand, the share of the rural population in Poland in the total population of the country has steadily declined, from the original $63.1 \%$ to about $40 \%$ (Table 1).

According to statistics, in Romania, almost $44 \%$ of the population lives in rural areas. As it can see in table 1 in Romania the situation is a little different, rural population is in a continuous decreasing. About the share of rural population we can mention that it can observe after a decreasing between 1950 and 1980 it is almost constatnt in last 30 years.

According to data from the National Institute of Statistics from Romania, in rural areas at January 1, 2015, the 2861 communes are domicile for 9.71 million people. The average size of municipalities in terms of the number of people residing in the locality was 3393 people. Compared to the average, extremes are found in Floreşti (Cluj County) with 24941 inhabitants and Bătrâna (Hunedoara County) with 131 inhabitants. The main factors that determines the decreasing of rural population are: labor migration, low birth rate, aging population. Migration is a common phenomena among young people, especially women, who due to lack of employment choose to go abroad or to urban areas. Declining birth rate is determined by the economic situation, but also the attitude of the couple to marriage, family and child birth. (Populația României pe localități la 1 ianuarie 2015) 
Table 1. Rural population

\begin{tabular}{|c|c|c|c|c|c|c|}
\hline \multirow[b]{2}{*}{ Year } & \multicolumn{3}{|c|}{ POLAND } & \multicolumn{3}{|c|}{ ROMANIA } \\
\hline & $\begin{array}{c}\text { Rural } \\
\text { population } \\
{[\mathrm{mln}]}\end{array}$ & $\begin{array}{l}\% \text { of total } \\
\text { population }\end{array}$ & $\begin{array}{c}\text { Absolute } \\
\text { increment } \\
\text { with } \\
\text { variable } \\
\text { basis [mln] }\end{array}$ & $\begin{array}{c}\text { Rural } \\
\text { population } \\
\text { [mln] }\end{array}$ & $\begin{array}{l}\% \text { of total } \\
\text { population }\end{array}$ & $\begin{array}{c}\text { Absolute } \\
\text { increment } \\
\text { with } \\
\text { variable } \\
\text { basis [mln] }\end{array}$ \\
\hline 1950 & 15.79 & 63.1 & - & $12,15^{1}$ & 76.6 & - \\
\hline 1955 & 15.48 & 56.2 & -0.31 & $12,02^{2}$ & 68.7 & -0.13 \\
\hline 1960 & 15.39 & 51.7 & -0.09 & 12.94 & 67.88 & 0.92 \\
\hline 1970 & 15,57 & 47.7 & 0.18 & 12.78 & 63.14 & -0.16 \\
\hline 1980 & 14.75 & 41.3 & -0.82 & 12.02 & 54.18 & -0.76 \\
\hline 1990 & 14.56 & 38.2 & -0.19 & 10.85 & 46.78 & -1.17 \\
\hline 1995 & 14.27 & 38.1 & -0.29 & 10.24 & 45.10 & -0.61 \\
\hline 2000 & 14.58 & 38.1 & 0.31 & 10.19 & 45.40 & -0.05 \\
\hline 2004 & 14.70 & 38.5 & 0.12 & 9.88 & 46.10 & -0.31 \\
\hline 2007 & 14.80 & 38.83 & 0.10 & 9.42 & 45.10 & -0.46 \\
\hline 2008 & 14.85 & 38.93 & 0.05 & 9.45 & 45.90 & 0.03 \\
\hline 2009 & 14.89 & 39.01 & 0.04 & 9.39 & 46.10 & -0.06 \\
\hline 2010 & 15.11 & 39.23 & 0.22 & 9.32 & 46.10 & -0.07 \\
\hline 2011 & 15.15 & 39.32 & 0.04 & 9.26 & 46.00 & -0.08 \\
\hline 2012 & 15.20 & 39.44 & 0.05 & 9.23 & 46.00 & -0.03 \\
\hline 2013 & 15.24 & 39.58 & 0.04 & 9.21 & 46.10 & -0.02 \\
\hline 2014 & 15.26 & 39.66 & 0.02 & 9.72 & 43,5 & 0.51 \\
\hline 2015 & 15.27 & 39.73 & 0.01 & 9.71 & 43.6 & -0.02 \\
\hline
\end{tabular}

https://bdl.stat.gov.pl/BDL/dane/podgrup/tablica, Baza de date Tempo-Online, INS, Bucureşti, 2017, Mateoc-Sîrb, N., 2012; ${ }^{1}$ year 1948, ${ }^{2}$ year 1956

The continuation of a similar state of the rural population does not mean that there were no significant changes within the group. Several generations have been exchanged, with the new generation of farmers having better characteristics than the one leaving (WAWRZYNIAK, 2004).

By analyzing the village population by sex and age, it is noteworthy that the relative balance between men and women is maintained in relation to the whole population. On the other hand, when analyzing this phenomenon in the age group of individual groups, there was a rapid collapse of these proportions among the elderly. The number of women aged 65 and over is twice as high as that of men (AGRICULTURAL STATISTICS, 2005).

Researchers on this issue wonder what the correct proportions should be for each age group in order to maintain adequate generational rotation and to ensure that the descendants of the production sphere are guaranteed a generation of successors who are ready to serve as young hosts. If we take into account the whole population for 100 , children and adolescents (0-17 years) account for about $23 \%$, people of working age (1864) $62.0 \%$, and people of retirement age (65 and over) Make up 13.5\%. As a result of the demographic process, there is a significant decrease in the population of children and adolescents, which in recent years has been around 30\%. Reducing the fertility of rural families can jeopardize the correct rotation of generations, unless the other parameters of the farm change in size and concentration of the soil, thereby contributing to the emergence of a new agrarian structure (BASIC INFORMATION, 2015) (Table 2). 
Review on Agriculture and Rural Development 2017 vol. 6 (1-2) ISSN 2063-4803

Table 2. Rural population by gender and age group, 2015

\begin{tabular}{|l|c|c|c|c|c|c|c|c|}
\hline \multirow{3}{*}{ Age group } & \multicolumn{4}{|c|}{ POLAND } & \multicolumn{4}{c|}{ ROMANIA } \\
\cline { 2 - 9 } & \multicolumn{2}{|c|}{ Male } & \multicolumn{2}{c|}{ Female } & \multicolumn{2}{c|}{ Male } & \multicolumn{2}{c|}{ Female } \\
\cline { 2 - 9 } & No & $\%$ & No & $\%$ & No & $\%$ & No & $\%$ \\
\hline $0-2$ & 236152 & 3.10 & 223091 & 2.91 & 143092 & 2.94 & 135630 & 2.79 \\
\hline $3-6$ & 353789 & 4.65 & 335820 & 4.39 & 210493 & 4.32 & 199998 & 4.12 \\
\hline $7-12$ & 523613 & 6.88 & 496752 & 6.49 & 339391 & 6.97 & 320902 & 6.62 \\
\hline $13-15$ & 261960 & 3.44 & 248938 & 3.25 & 186665 & 3.83 & 176314 & 3.63 \\
\hline $16-19$ & 380167 & 4.99 & 355526 & 4.64 & 246217 & 5.05 & 232622 & 4.80 \\
\hline $20-24$ & 575957 & 7.57 & 549312 & 7.17 & 327319 & 6.72 & 300681 & 6.20 \\
\hline $25-34$ & 1232363 & 16.19 & 1146151 & 14.97 & 730469 & 15.00 & 647190 & 13.35 \\
\hline $35-44$ & 1167716 & 15.34 & 1100262 & 14.37 & 825770 & 16.96 & 723920 & 14.93 \\
\hline $45-54$ & 1018711 & 13.38 & 943290 & 12.32 & 652602 & 13.40 & 539526 & 11.13 \\
\hline $55-64$ & 1016529 & 13.35 & 972602 & 12.70 & 520862 & 10.70 & 542094 & 11.18 \\
\hline 65 and over & 846335 & 11.12 & 1285774 & 16.79 & 683683 & 14.04 & 1027032 & 21.19 \\
\hline Total & 7613292 & 100.00 & 7657518 & 100.00 & 4866563 & 100.00 & 4845909 & 100.00 \\
\hline
\end{tabular}

Source: Statistical Yearbook of Agriculture and Rural Areas, Central Statistical Office, Warsaw 2016

The demographic process illustrates the natural biological and social phenomena between the emergence of new life and the genetic depletion of the possibility of its further existence. In 2014, 151.2 thousand were born in the countryside. Children, while the birth rate was $10.3 \%$ (in the city $8.5 \%$ ). For at least 10 years, the level of reproduction does not guarantee a simple substitution of generations. The decline in the number of births indicates that the village is increasingly adopting the $2+1$ or $2+2$ family urban model. The number of marriages is still the most affected because the vast majority of children are born in families formed by legally incorporated (BASIC INFORMATION, 2015).

In Romania, the population aged between 40 and 44 years have a share of $8 \%$, the young population (0-14 years) are 1,583.8 thousand people (66.1\%) and the elderly (65 years and over) holds $17.6 \%$ of the total rural population.

A positive phenomenon observed for several years is the steady increase in the number of persons with post-primary education. Between 1996 and 2002, the proportion of people with post-primary education increased from 51.5\% in 1996 to $59.7 \%$ in $2002(8.2$ percentage points). The number of people with primary school education and no schooling was significantly reduced from $48.5 \%$ to $39.9 \%$. At the same time, there was an almost double increase in the number of people with higher education. (WAWRZYNIAK AND WOJTASIK, 2004).

An ever-smaller gap in the acquisition of education divides the inhabitants of rural and urban areas. Although urban populations have a significantly higher percentage of people with post-primary education (in 2014-73\%), rural populations are rapidly increasing their education. At the same time, more than twice the percentage of people without school education decreased in rural areas.

In the countryside, however, the older generation, and especially women who live longer, has only primary and secondary education. This phenomenon tends to decrease due to the natural biological process associated with leaving the elderly.

Education is the education category that exerts an impact on social mobility, migration processes, and trends in job change. An educated person is not permanently assigned to the ground, because he has another alternative; he can focus on non-agricultural but often in his own environment and perform social roles that require more knowledge of the world. 


\section{CONCLUSIONS}

Demographic processes in rural areas allow for the analysis of completely new phenomena occurring in these areas. The village differs in many important details from the city, but as a result of the interpenetration of the value system between these populations, we tend to unify certain phenomena. This concerns in particular taking care of the educational opportunity of children and young people, seeking a new career path, creating new patterns of marriages, family reunion or expanding family standards, both in the material and in the material sphere.

The analysis shows that there are too many people in the countryside in relation to the area of the agricultural land and the number of farms. We can even talk about relative agrarian overpopulation, which results in waste of human capital and lower productivity and lower incomes.

The village is rapidly recovering its civilizational and educational backlog. Aspiring for new trends in the world as a result of globalization is not just a feature of urban environments. At the same time, the village welcomes the traditional values of family, religion, opinion and behavior in the rural environment.

The properties of a farm result in the fact that a successor, a mature, but matured person, is next to the owner of the holding. The length of life causes the generation rotation to be impeded, while the bad agrarian structure does not allow the division of farms. Hence, the introduction of structural pensions can have a positive impact on these phenomena.

\section{REFERENCES}

BRAD I., IANCU T., TOADER COSMINA-SimONA (2011): Aspects concerning the demographic compound of the Romanian rural area, Lucrări Științifice - vol. 54, Supliment/2011, seria Agronomie, p. 94-99

MATEICA, C.S. (2010): Managementul dezvoltării rurale durabile în zona colinară a judetului Timis, Teza de doctorat

MATEOC-SîRB, N. (2002): Dezvoltare rurală și regional în Romania, Ed. Agroprint, Timișoara

WAWRZYNIAK B.M. (2004): Przemiany struktury agrarnej w rolnictwie polskim, WTN, Włocławek

WAWRZYNIAK B.M., WOJTASIK B. (2004a): Tendencje zmian poziomu wykształcenia ludności rolniczej, Zagadnienia Doradztwa Rolniczego, $\mathrm{nr} 4$

WAWRZYNIAK B.M., WOJTASIK B. (2004b): Zmiany wykształcenia mieszkańców wsi w latach 1996-2002, ACTA Oeconomia, nr 3

WAWRZYNIAK B.M., WOJTASIK B. (2005): Ubezpieczenia społeczne rolników, WTN, Włocławek

*** - Agricultural statistics, 2005

*** - Basic Information, 2015

*** - Baza de date Tempo-Online, INS, Bucureşti, 2017

*** - Local data bank https://bdl.stat.gov.pl/BDL/dane/podgrup/wymiary

*** - Podstawowe informacje o rozwoju demograficznym Polski do 2014r, 2015, GUS,

Warszawa

*** - Rocznik statystyczny rolnictwa i obszarów wiejskich, 2015. GUS, Warszawa

*** - Statistical Yearbook of Agriculture and Rural Areas, Central Statistical Office, Warsaw 2016 
*** - Ustawa o rentach strukturalnych w rolnictwie z 2001r z póżniejszymi zmianami [Dz. U. nr 52, poz. 539]

*** - Ustawa o samorządzie gminnym z 1990r, [Dz. U. nr 32, poz. 324]

*** - Populația României pe localități la 1 ianuarie 2015, INS Romania (www.insse.ro/cms/files/publicatii/pliante\%20statistice/Populatia\%20Romaniei\%20pe\%20 localitati\%201a\%201\%20ian\%202015.pdf) 